\title{
Cyclosporin A in refractory idiopathic nephrotic syndrome: 5 years clinical experience
}

\author{
M.P. Delaney, D.C. Dukes and M.E. Edmunds
}

Walsgrave Hospital, Coventry, UK

Summary: The use of cyclosporin A (Cy A) in idiopathic nephrotic syndrome, particularly lesions of focal segmental glomerular sclerosis, is controversial. A retrospective study of 10 adult patients with nephrotic syndrome treated with Cy A was performed. Histological diagnosis was established in all patients: focal segmental glomerular sclerosis $(n=6)$, focal global sclerosis $(n=1)$, mesangial proliferative glomerulonephritis $(n=1)$, focal proliferative glomerulonephritis $(n=1)$ and minimal change disease $(n=1)$.

All patients had previously received immunosuppressive therapy (duration of steroids 1-76 months; $35.0 \pm 12.1$, mean \pm SEM). Cy $A$ in a dose of $3-5 \mathrm{mg} / \mathrm{kg} /$ day, reduced proteinuria from $16.85 \pm 6.67$ to $3.37 \pm 1.48 \mathrm{~g} / 24$ hours $(P=0.008)$, with an associated increase in serum albumin from $15.2 \pm 2.6$ to $34.3 \pm 2.5 \mathrm{~g} / \mathrm{l}(P<0.001)$.

In six patients steroid therapy was discontinued. Cy A was well tolerated for up to 5 years. There was no significant nephrotoxicity.

In conclusion, $\mathrm{Cy} \mathbf{A}$ was effective treatment of refractory idiopathic nephrotic syndrome, including those cases with focal segmental glomerular sclerosis.

\section{Introduction}

The management of refractory idiopathic nephrotic syndrome remains a significant problem. It is a debilitating condition as infection may supervene and progression of the disease can lead to terminal renal insufficiency.

'Idiopathic' nephrotic syndrome encompasses two main forms of glomerular disease, namely minimal change disease (MCD) and focal segmental glomerulosclerosis (FSGS). MCD is primarily a disease of children, which generally responds to steroids. ${ }^{1}$ Patients may develop dependence on steroids and require repeated or continuous treatments, which inevitably leads to features of glucocorticoid toxicity. Resistance to steroids can occur. Alkylating agents such as cyclophosphamide and chlorambucil have also been shown to induce remission, ${ }^{2,3}$ however, the potential side effects, particularly gonadal toxicity, have limited their use. Nephrotic syndrome accompanied by lesions of FSGS carries a poor prognosis, with only $20 \%$ of cases responding to steroids. ${ }^{4} \mathrm{Up}$ to $50 \%$ of patients with the FSGS lesion will have developed end-stage renal failure within 10 years. ${ }^{5}$

Correspondence: M.P. Delaney, B.Sc., M.R.C.P., c/o Renal Services, Walsgrave Hospital NHS Trust, Clifford Bridge Road, Coventry CV2 2DX, UK.

Accepted: 25 April 1994
In recent years, cyclosporin $\mathrm{A}(\mathrm{Cy} \mathrm{A})$ has been used in the treatment of nephrotic syndrome, both in adults and children. ${ }^{6-11}$ Reports confirm favourable response rates in cases of steroid-dependent MCD of up to $70 \%$ and disappointing response rates of $20 \%$ in FSGS. ${ }^{9}$ This report examines the clinical experience of Cy A therapy in cases of refractory nephrotic syndrome.

\section{Patients and methods}

A retrospective study was performed to examine patients with refractory nephrotic syndrome commenced on Cy A. The patients had either become resistant to conventional treatment or had developed features of marked toxicity. All patients treated with $\mathrm{Cy} \mathrm{A}$ were included in the study. Ten patients (nine male, one female) with an age range of 23-68 years were studied. Histological examination was performed on renal biopsies from all patients. Six patients had FSGS, one patient focal global sclerosis, one patient mesangial proliferative glomerulonephritis, one patient focal proliferative glomerulonephritis and one with MCD. All patients had previously received immunosuppressive therapy (duration of steroid treatment between 1 and 76 months; $35.9 \pm 12.21$; mean \pm SEM), including four patients who had also received either 
cyclophosphamide or azathioprine. Cy A was given in addition to maintenance steroids in a dose of $3-5 \mathrm{mg} / \mathrm{kg} / \mathrm{day}$. Levels were maintained at $50-150$ $\mu \mathrm{g} / \mathrm{l}$. Blood Cy A levels were measured by standard radioimmunoassay. The pre-Cy A range of proteinuria was from 3 to $60 \mathrm{~g} / 24$ hours (mean \pm s.e.m. $16.85 \pm 6.67$ ). Proteinuria, serum albumin, serum creatinine and clinical course were monitored. Immunosuppressive regimes were altered according to clinical response. The patients' characteristics are shown in Table I.

\section{Definitions}

Nephrotic range proteinuria: greater than $3 \mathrm{~g} / 24$ hours. Complete remission: proteinuria $<1 \mathrm{~g} / 24$ hours. Partial remission: a significant fall in proteinuria, associated with a rise in serum albumin and improvement in clinical condition.

\section{Statistical methods}

Paired $t$ tests were used. $P$ values $<0.05$ were taken as significant. Results are expressed as mean \pm SEM.

\section{Results}

There was a highly significant reduction in proteinuria with the introduction of Cy A therapy. The mean daily protein excretion fell from $16.85 \pm 6.67$ to $3.37 \pm 1.48 \mathrm{~g} / 24$ hours $(P=0.008)$. This was associated with an increase in serum albumin from $15.2 \pm 2.62$ to $34.3 \pm 2.49 \mathrm{~g} / 1(P<0.001)$ (Table II). Seven patients achieved full remission and three patients partial remission (reduction of proteinuria from 60.0-14.0, 16.2-8.0, 24.0-7.0 g/24 hours).

Sustained responses of between 12 to 60 months were seen in eight patients. One patient relapsed after 4 months, and required manipulation of corticosteroids and $\mathrm{Cy}$ A dose to induce a sustained remission. One patient responded well to treatment but did not comply with treatment. This was confirmed by unrecordable Cy A levels on occasion of relapse. In six patients it was possible to withdraw steroids completely. The treatment was well tolerated (Table III). In three patients (nos. 6-8), who had significantly impaired renal function prior to treatment, there was an improvement in serum creatinine with the introduction of $\mathrm{Cy} \mathrm{A}$ and the reduction of diuretic therapy. In three patients there was an increase in serum creatinine to just above the normal range (nos. $1,4,10$ ). The remaining patients continued to have serum creatinine within the normal range for a period of up to 60 months on treatment. Cy A did not have to be discontinued in any patient due to nephrotoxicity.

Mild increases in blood pressure were noted in three patients. These patients were managed easily with anti-hypertensive therapy. Two patients had myocardial infarcts following 24 and 48 months of treatment.

\section{Discussion}

This study demonstrates the effectiveness of $\mathrm{Cy} A$ in patients with severe idiopathic nephrotic syno drome. Six patients with FSGS responded to treatment, three of whom obtained complete remission.

FSGS is often resistant to treatment, with less than $20 \%$ of patients attaining complete remission with corticosteroids. ${ }^{4}$ A recent large study by Meyrier et al. demonstrated that, in $50 \%$ of 'steroid-sensitive' cases, Cy A reduced proteinuria. In steroid-resistant cases only $20 \%$ obtained remission. ${ }^{9}$ The current study of a small number of

Table I Patient characteristics

\begin{tabular}{|c|c|c|c|c|c|c|c|c|c|c|}
\hline Patient no. & 1 & 2 & 3 & 4 & 5 & 6 & 7 & 8 & 9 & 10 \\
\hline Age (years) & 33 & 23 & 32 & 29 & 50 & 68 & 60 & $66^{*}$ & 30 & 52 \\
\hline $\begin{array}{l}\text { Years since } \\
\text { diagnosis }\end{array}$ & 4 & 21 & 4 & 12 & 5 & 3 & 11 & 6 & 28 & 3 \\
\hline $\begin{array}{l}\text { Renal } \\
\text { histology }\end{array}$ & FSGS & $\begin{array}{c}\text { Focal } \\
\text { global } \\
\text { sclerosis }\end{array}$ & FSGS & FSGS & $\begin{array}{c}\text { Mesangial } \\
\text { proliferative }\end{array}$ & FSGS & $\begin{array}{c}\text { Focal } \\
\text { proliferative }\end{array}$ & FSGS & MCD & FSGS \\
\hline $\begin{array}{l}\text { Duration of } \\
\text { steroid } \\
\text { therapy } \\
\text { (months) }\end{array}$ & 5 & 75 & 3 & 72 & 5 & $1 \dagger$ & 76 & 24 & 75 & 3 \\
\hline $\begin{array}{l}\text { Previous } \\
\text { cytotoxic } \\
\text { therapy }\end{array}$ & - & + & - & + & - & - & + & - & + & - \\
\hline
\end{tabular}

*Only female patient; $\nmid$ steroid-induced hyperosmolar state. 
Table II Efficacy

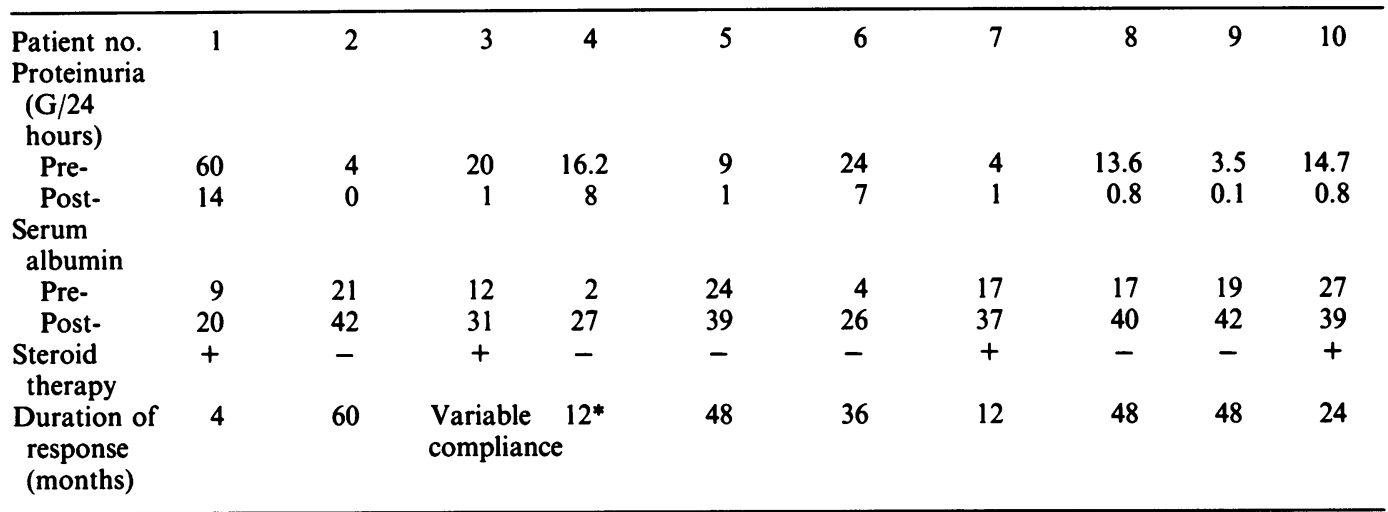

*Lost to follow-up.

Table III Toxicity

\begin{tabular}{|c|c|c|c|c|c|c|c|c|c|c|}
\hline $\begin{array}{l}\text { Patient no. } \\
\text { Serum } \\
\text { creatinine } \\
(\mu \mathrm{mol} / \mathrm{l})\end{array}$ & 1 & 2 & 3 & 4 & 5 & 6 & 7 & 8 & 9 & 10 \\
\hline $\begin{array}{l}\text { Pre- } \\
\text { Post- }\end{array}$ & $\begin{array}{l}100 \\
146\end{array}$ & $\begin{array}{l}78 \\
90\end{array}$ & $\begin{array}{l}84 \\
80\end{array}$ & $\begin{array}{r}86 \\
125\end{array}$ & $\begin{array}{l}94 \\
98\end{array}$ & $\begin{array}{l}340 \\
190\end{array}$ & $\begin{array}{l}135 \\
122\end{array}$ & $\begin{array}{r}146 \\
90\end{array}$ & $\begin{array}{r}67 \\
100\end{array}$ & $\begin{array}{l}107 \\
129\end{array}$ \\
\hline $\begin{array}{l}\text { Blood } \\
\text { pressure }\end{array}$ & - & + & - & - & + & - & - & $-^{*}$ & + & $-^{*}$ \\
\hline
\end{tabular}

*Suffered myocardial infarction.

patients observed for 1-5 years demonstrates a very good response with a moderate dose of $\mathrm{Cy} \mathrm{A}$.

The mechanism of action of $\mathrm{Cy} \mathrm{A}$ in nephrotic syndrome is yet to be fully elucidated. It has been postulated that any glomerular insult (so far undefined) may lead to the production of lymphokines, including interleukin 1 and 8 , which are chemotactic for macrophages and $T$ cells, causing a brisk inflammatory response resulting in focal glomerulosclerosis and declining renal function. ${ }^{12}$ Cy $A$ is one of a family of cyclic peptides produced by the fungus Tolypocladium inflatus Gams. It inhibits the production and release of interleukins and gamma interferon, and is thus a potent immunosuppressor. ${ }^{13}$

An alternative, non-immunological, mechanism for reduction of proteinuria is by alteration of intrarenal haemodynamics, as Cy A is recognized to cause intrarenal vasoconstriction, probably of the afferent arteriole, associated with a decrease in glomerular filtration rate. ${ }^{7}$ More recent work has suggested that $\mathrm{Cy} \mathrm{A}$ restores charge selectivity to the glomerular basement membrane, thereby reducing the membrane permeability. ${ }^{14}$

Cy A-related nephrotoxocity is well recognized ${ }^{15}$ and it is important to consider the potential nephrotoxic effects, particularly in patients with already low glomerular filtration rates secondary to FSGS. In our experience, the following guidelines should be considered. The dose of Cy A should not exceed $5 \mathrm{mg} / \mathrm{kg} /$ day in adults. Blood levels should be checked one month following the introduction of treatment and, providing these are satisfactory, at two-monthly intervals thereafter. Trough levels are used and levels ranging between 50 and $150 \mu \mathrm{g} / \mathrm{l}$ attained. Certain drugs may lead to increased nephrotoxicity if given concomitantly with Cy A. For example, non-steroidal anti-inflammatory drugs, angiotensin converting enzyme inhibitors and antibiotics, including erythromycin, should be used with caution.

Serum creatinine, similarly, should be measured at 1 month, then at 2-monthly intervals, and dosage of $\mathrm{Cy} \mathrm{A}$ adjusted if serum creatinine increases significantly above the baseline. The drug should be avoided or discontinued in patients with a serum creatinine which is above $200 \mu \mathrm{mol} / \mathrm{l}$.

Conversely, improvements in serum creatinine may be seen in those patients obtaining a response to treatment, which permits a reduction in diuretic requirements. A trial of therapy should be discontinued if a significant reduction in proteinuria is not 
achieved within 2-3 months. It is encouraging that none of the patients in the study developed severe nephrotoxicity. Similarly, only moderate elevations of blood pressure were observed.

In conclusion, $\mathrm{Cy} \mathrm{A}$ is an effective and welltolerated treatment of refractory idiopathic nephrotic syndrome, including those patients with FSGS.

\section{References}

1. Makker, S.P. \& Heymann, W. The idiopathic nephrotic syndrome of childhood: a clinical re-evaluation of 145 cases. Am J Dis Child 1974, 127: 830-837.

2. Barratt, T.M., Osofsky, F.G., Berkowskey, A., Soothill, J.F. \& Kay, R. Cyclophosphamide treatment in steroid sensitive nephrotic syndrome of childhood. Lancet 1975, i: 55-58.

3. Grupe, W.E., Makker, S.P. \& Ingelfinger, J.R. Chlorambucil treatment of frequently relapsing nephrotic syndrome. $N$ Engl J Med 1976, 295: 746-749.

4. Ponticelli, C. \& Rivolta, E. Ciclosporin in minimal-change glomerulopathy and in focal segmental glomerular sclerosis. Am J Nephrol 1990, 10 (Suppl 1): 105-109.

5. Brown, C.B., Cameron, J.S., Turner, D.R. et al. Focal segmental glomerulosclerosis with rapid decline in renal function (malignant FSGS). Clin Nephrol 1978, 10: 51-61.

6. Meyrier, A., Simon, P., Penet, G. \& Condamin-Myrier, M.C. Remission of idiopathic nephrotic syndrome after treatment with Cyclosporin A. Br Med J 1986, 292: 789-792.

7. Zietse, R., Wenting, G.J., Kramer, P., Mulder, P., Schalekamp, M.A. \& Weimar, W. Contrasting response to cyclosporin in refractory nephrotic syndrome. Clin Nephrol 1989, 31: $22-25$.

8. Waldo, F.B. \& Kohaut, E.C. Therapy of focal segmental glomerulosclerosis with cyclosporin A. Pediatr Nephrol 1987, 1: $180-182$.

\section{Acknowledgements}

The authors would like to thank Miss Karen Gould for her help in preparing the manuscript.

9. Meyrier, A., Condamin, M.-C., Broneer, D. \& The Collaborative Group of the French Society of Nephrology. Treatment of adult idiopathic nephrotic syndrome with cyclosporin A: minimal-change disease and focal-segmental glomerulosclerosis. Clin Nephrol 1991, 35 (Suppl 1): 37-42.

10. Niaudet, P., Habib, R., Tete, M.J., Hinglais, N. \& Broyer, M. Cyclosporine in the treatment of idiopathic nephrotic syndrome in children. Pediatr Nephrol 1987, 1: 566-573.

11. Tanaka, R., Yoshikawa, N., Kitano, Y., Ito, H. \& Nakamura, $H$. Long-term cyclosporin treatment in children with steroid-dependent nephrotic syndrome. Pediatr Nephrol 1993, 7: 249-252.

12. Wardle, E.N. Cellular biology of glomerulosclerosis. Nephrol 1992, 61: 125-128.

13. Borel, J.F. Mechanism of action of cyclosporin A and rationale for use in nephrotic syndrome. Clin Nephrol 1991, 35 (Suppl 1): 23-30.

14. Zietse, R., Wenting, G.J., Kramer, P., Schalekamp, M.A. \& Weimer, W. Effects of cylosporin A on glomerular barrier function in the nephrotic syndrome. Clin Sci 1992, 82: 641-650.

15. Puschett, J.B., Greenberg, A., Holley, J. \& McCauley, J. The spectrum of cyclosporin nephrotoxicity. Am J Nephrol 1990, 10: $296-309$. 